\title{
Ehrlichia canis (Jaboticabal strain) induces the expression of TNF- $\alpha$ in leukocytes and splenocytes of experimentally infected dogs
}

\author{
Amostra Ehrlichia canis (Jaboticabal) induz a expressão de TNF- $\alpha$ em leucócitos e esplenócitos \\ de cães experimentalmente infectados \\ Joice Lara Maia Faria ${ }^{1}$; Thiago Demarchi Munhoz ${ }^{2}$; Carolina Franchi João ${ }^{3}$; Giovanny Vargas-Hernández²; \\ Marcos Rogério André2; Wanderson Adriano Biscola Pereira ${ }^{1}$; Rosângela Zacarias Machado²; Mirela Tinucci-Costa ${ }^{2 *}$ \\ ${ }^{1}$ Universidade de Uberaba - UNIUBE \\ ${ }^{2}$ Universidade Estadual Paulista - UNESP \\ ${ }^{3}$ Universidade Federal do Pará - UFPA
}

Received June 14, 2010

Accepted November 17, 2010

\begin{abstract}
Canine ehrlichiosis is caused by the bacterium Ehrlichia canis and is characterized by a systemic febrile disease of unknown pathogenesis. This study evaluated the expression of cytokines TNF- $\alpha$, IL-10, IFN- $\gamma$, in splenic cells and blood leukocytes during the acute phase of ehrlichiosis and after treatment with doxycycline hyclate in dogs experimentally infected with the $E$. canis Jaboticabal strain. The study results showed a significant expression of TNF- $\alpha$ 18 days post-inoculation, reducing by approximately $70 \%$ after treatment. There was a unique peak of expression of IL-10 and IFN- $\gamma 18$ and 30 days post-inoculation, respectively. This study suggests that TNF- $\alpha$ plays a role in the pathogenesis of the acute phase of canine ehrlichiosis and that treatment with doxycycline hyclate reduces the systemic effects of this cytokine, possibly by reducing or eliminating parasitemia.
\end{abstract}

Keywords: Ehrlichiosis, dogs, experimental infection, IL-10, IFN- $\gamma$.

\section{Resumo}

A erliquiose canina é causada pela bactéria Ehrlichia canis, que desencadeia no hospedeiro uma doença febril e sistêmica, de patogênese pouco conhecida. O presente estudo avaliou a expressão das citocinas TNF- $\alpha$, IL-10, IFN- $\gamma$, em células esplênicas e em leucócitos sanguíneos, durante a fase aguda da erliquiose e após o tratamento com hiclato de doxiciclina, em cáes experimentalmente infectados com a amostra E. canis Jaboticabal. Os resultados mostraram expressão significativa de TNF- $\alpha 18$ dias após a inoculação, reduzindo aproximadante $70 \%$ após o tratamento. Houve um único pico de expressão de IL-10 e de IFN- $\gamma$ entre 18 e 30 dias após a inoculação, respectivamente. Este estudo sugere que o TNF- $\alpha$ participa da patogenia da fase aguda da erliquiose canina, e que o tratamento com hiclato de doxiciclina reduz os efeitos sistêmicos dessa citocina, possivelmente por reduzir ou eliminar a parasitemia.

Palavras-chave: Erliquiose, cães, infecção experimental, IL-10, IFN- $\gamma$.

Canine ehrlichiosis is a disease transmitted by ticks and caused by the gram-negative bacterium Ehrlichia canis, from genus Ehrlichia and family Anaplasmataceae (DUMLER et al., 2001). The acute phase of this disease begins about 8 to 21 days post-infection and lasts for two to four weeks (NEER; HARRUS, 2006). It is

\footnotetext{
${ }^{*}$ Corresponding author: Mirela Tinucci-Costa

Departamento de Cirurgia e Clínica Veterinária,

Universidade Estadual Paulista - UNESP, campus de Jaboticabal,

Via de acesso Prof. Paulo Donatto Castellane, s/n,

CEP 14884-900, Jaboticabal - SP, Brazil;

e-mail: mirelatc@fcav.unesp.br
}

characterized by hyperthermia, weight loss, anorexia, enlarged lymph nodes, splenomegaly, vasculitis (HARRUS et al., 1999) and thrombocytopenia, which is the most common abnormality (WANER et al., 2000) found in dogs. The subclinical phase may last years indicating parasite persistence in the host (HARRUS et al., 1998) and the chronic phase is characterized by bleeding disorders and pancytopenia (HARRUS et al., 1999). The diagnosis may be established by direct identification of inclusion corpuscles or morulae of E. canis in the buffy coat (ELIAS, 1991), lymph nodes (MYLONAKIS et al., 2003) or splenic aspiration (FARIA et al., 2010); specific antibody detection (OLIVEIRA et al., 2000); or 
ehrlichial DNA detection by nested polymerase chain reaction (PCR) (NAKAGHI et al., 2008). The treatment of choice is doxycycline hydrochloride for 21 days (HARRUS et al., 1999; NEER; HARRUS, 2006). Dogs are free of parasites when the ehrlichial DNA is no longer detected in the blood or tissues after treatment (EDDLESTONE et al., 2007).

Although immunopathological mechanisms of diseases caused by species from Anaplasmataceae family have been investigated in many studies, the knowledge on these disease is still limited. Studies have shown that IFN- $\gamma$ has a protective role in the host against Anaplasma phagocytophilum (MARTIN; CASPERSEN; DUMLER, 2001), and this protective effect seems to be enhanced by TNF- $\alpha$, a pro-inflammatory cytokine (FENG; WALKER, 2004). In contrast, some of these studies have highlighted that the immune response to microorganisms of this family may cause damage to the host's tissues (SCORPIO et al., 2006). Regarding the profile of cytokines produced in rickettsial diseases, it has been suggested that pro-inflammatory cytokines (IL1 $\beta$, IL-6, IL-12 and TNF- $\alpha$ ) are associated to clinical aggravation of disease with activation of inflammatory cells and induction of nitric oxide production by macrophages. However, cytokines such as IL-10 and TGF- $\beta$ may be involved in the modulation of immune response and disease remission (BEINEKE et al., 2008). There are only few studies about cytokines in ehrlichiosis caused by E. canis. Unver, Huang and Rikihisa (2006) have detected significant levels of IL-1 $\beta$ and IL-8 in dogs with ehrlichiosis and suggested that these cytokines could be responsible for the observed clinical signs. In another study, researchers inoculated E. canis Oklahoma in dogs and found that disease severity and the profile of cytokines produced may vary according to the infecting strain (TAJIMA; RIKIHISA, 2005). It is known that ehrlichiosis in dogs is a febrile disease with severe hematological disturbances; from the moment these pathogens penetrate the animal's body, there is agent dissemination through mechanisms not yet clear. Although unknown, the immune response against $E$. canis is ineffective. Thus, the present study aimed to evaluate the expression of TNF- $\alpha$, IL-10, IFN- $\gamma$ during the acute phase of ehrlichiosis and post-treatment with doxycycline hyclate (5.0 mg. $\mathrm{kg}^{-1} \mathrm{PO} / \mathrm{bid} / 21$ days) in dogs experimentally infected with pure E. canis Jaboticabal strain (Gene Bank $\mathrm{n}^{\circ} \mathrm{DQ}$ 401044). The study was approved by the Ethics and Animal Welfare Committee (CEBEA) at the Universidade Estadual de São Paulo (UNESP), Jaboticabal campus (protocol number 002460-08). The evaluations were performed before the experimental infection (Day -1$)$ and $6,18,30$ and 76 days post-infection. Ten mongrel dogs from the same offspring, 5 males and 5 females, 2 years of age, born and raised at the experimental kennel at the Veterinary University Hospital at UNESP/Jaboticabal, fed with commercial feed and receiving water ad libitum were included in this study. The dogs were immunized against infectious diseases, dewormed and prophylactically treated with parasiticides. Before the experiment, the absence of $E$. canis infection was confirmed through indirect immunofluorescence reaction (IFAT) and nested polymerase chain reaction (nPCR) for Babesia canis. The dogs were then randomly divided into 2 groups. Five dogs were inoculated with $1.0 \mathrm{~mL}$ of DH82 cells infected by E. canis Jaboticabal strain (Ec group) and the remaining five were controls (control group). After inoculation, the dogs from Ec group and controls were examined on a daily basis and complete blood counts were regularly performed. The onset of parasitemia was accompanied by the investigation of morulae in the blood smear from the ear tip (ELIAS, 1991). Blood and spleen samples (spleen samples were obtained by fine needle aspiration) were collected prior to the inoculation, at Day -1 and after the inoculation at Day 6*, Day $18^{*}$, Day $30^{*}$ and after treatment with doxycycline hyclate $\left(\mathrm{D} 76^{*}\right)$. They were used for investigating cytokine gene expression using mRNA reverse transcription technique (RT-PCR) (CHAMIZO et al., 2001). For infection confirmation and assessment of treatment response, IFAT and nPCR were repeated at Day 18 and Day 76.

Three days after experimental infection, the dogs in the Ec group had thrombocytopenia, leukopenia and anemia, anorexia, fever, enlarged lymph nodes and splenomegaly. Thrombocytopenia and leukopenia lasted until the end of the experiment. Intracytoplasmic morulae were found in blood smears of ear tip blood of dogs in the Ec group from Day 15 on, confirming parasitemia and infection by $E$. canis. The clinical progress was similar to that reported by Castro et al. (2004) while studying the same E. canis strain. At Day 18 and Day 76, the dogs from the control group remained negative in the anti- $E$ canis IFAT, quite the opposite of what was seen in dogs in the Ec group at both time points. The titles have ranged from $1: 2.560$ to $1: 5.120$ at Day 18 to $1: 320$ to $1: 2.560$ at Day 76.

All animals in all time points remained negative in the anti-B. canis IFAT. E. canis DNA was detected in dogs from Ec group at Day 18 and was negative after treatment (Day 76), showing that treatment with doxycycline hyclate effectively eliminated infection, which is consistent with the results obtained by Eddlestone et al. (2007). The three targeted genes were expressed in animals in the Ec group and in some dogs in the control group, and TNF- $\alpha$ had the highest and most persistent expression. This gene expression was observed from Day 6 on with a mean rate of 0.40 only in leukocytes from the control group, and 0.05 in leukocytes and 0.77 in splenocytes from the Ec group.

At Day 18 TNF- $\alpha$ expression significantly increased in the Ec group compared to controls. The mean expression rate in leukocytes was 1.46 and in splenocytes was 3.99 in the Ec group, while it was 0.38 only in leukocytes in controls. At Day 30, TNF- $\alpha$ in the Ec group reached its highest expression level, around 2.88 in leukocytes and 4.14 in splenocytes. Among controls, the mean expression rate was 0.03 in leukocytes and 1.83 in splenocytes. At Day 76, a reduction of TNF- $\alpha$ gene expression occurred in all animals in both $\mathrm{Ec}$ and control group. In the Ec group, the mean expression rate was 0.42 in leukocytes and 0.47 in splenocytes. In controls, the mean expression rate was 0.75 in leukocytes and there was no expression in splenocytes. TNF- $\alpha$ expression at Day 18 was significantly higher than at Day 0 and Day 6 . Between Day 30 and Day 76, it was not significantly higher compared to other time points. Only at Day 18, IL-10 expression was detected at a mean rate of 1.23 in leukocytes and 1.87 in splenocytes in the Ec group and there was no expression in controls, with no significant different between both groups. Similarly, only at Day 30 IFN- $\gamma$ expression was seen in leukocytes from the Ec group, with

\footnotetext{
* Day 6 refers to 6 days post-inoculation, Day 18 to 18 days post-inoculation, Day 30 to 30 days post-inoculation and the beginning of treatment with doxycycline hyclate at $5 \mathrm{mg} \cdot \mathrm{kg}^{-1}$ BID PO for 21 days and Day 76 to 76 days post-inoculation and end of treatment.
} 
Table 1. Mean expression rate of IL-10, TNF- $\alpha$, and IFN- $\gamma$ in leukocytes and splenocytes of experimentally infected dogs (Ec and control groups).

\begin{tabular}{|c|c|c|c|c|c|c|c|}
\hline \multirow[t]{2}{*}{ Cytokines } & \multirow[t]{2}{*}{ Sample } & \multirow[t]{2}{*}{ Groups } & \multicolumn{5}{|c|}{ Evaluations } \\
\hline & & & Day -1 & Day 6 & Day 18 & Day 30 & Day 76 \\
\hline \multirow[t]{4}{*}{ TNF- $\alpha$} & Splenocytes & $\mathrm{Cn}$ & 0.0 & 0.00 & $0.00 \mathrm{a}$ & 1.83 & 0.00 \\
\hline & & Ec & 0.0 & 0.77 & $3.99 \mathrm{~b}$ & 4.14 & 0.47 \\
\hline & Leukocytes & $\mathrm{Cn}$ & 0.0 & 0.40 & $0.38 \mathrm{a}$ & 0.03 & 0.75 \\
\hline & & $\mathrm{Ec}$ & 0.0 & 0.05 & $1.46 \mathrm{~b}$ & 2.88 & 0.42 \\
\hline \multirow[t]{4}{*}{ IL-10 } & Splenocytes & $\mathrm{Cn}$ & 0.0 & 0.0 & $0.00 \mathrm{a}$ & 0.0 & 0.0 \\
\hline & & $\mathrm{Ec}$ & 0.0 & 0.0 & $1.87 \mathrm{~b}$ & 0.0 & 0.0 \\
\hline & Leukocytes & $\mathrm{Cn}$ & 0.0 & 0.0 & $0.00 \mathrm{a}$ & 0.0 & 0.0 \\
\hline & & Ec & 0.0 & 0.0 & $1.23 \mathrm{~b}$ & 0.0 & 0.0 \\
\hline \multirow[t]{4}{*}{ IFN- $\gamma$} & Splenocytes & $\mathrm{Cn}$ & 0.0 & 0.0 & 0.0 & 0.00 & 0.0 \\
\hline & & Ec & 0.0 & 0.0 & 0.0 & 0.00 & 0.0 \\
\hline & Leukocytes & $\mathrm{Cn}$ & 0.0 & 0.0 & 0.0 & 0.00 & 0.0 \\
\hline & & Ec & 0.0 & 0.0 & 0.0 & 1.50 & 0.0 \\
\hline
\end{tabular}

Note: Different letters in same column refer to significant differences $(\mathrm{p}<0.05)$ between Ec groups and controls.

a mean 1.50. In all animals and at all time points evaluated, the GAPDH gene was detected, showing the integrity of the extracted RNA. These results are presented in the Table 1.

High levels of TNF- $\alpha$ expression were found in dogs experimentally infected with $E$. canis (TAJIMA; RIKIHISA, 2005), and E. muris (FENG; WALKER, 2004), suggesting this gene is associated with the parasite's elimination. Thus, TNF- $\alpha$ plays a role in ehrlichial infection pathogenesis, which corroborates our results. Among its functions, TNF- $\alpha$ has a role in the immune response against bacteria and other agents, in addition to its essential activity in modulating local inflammatory immune response. TNF- $\alpha$ is an acute phase protein that induces a cytokine cascade and increases vascular permeability accompanied by macrophage and neutrophil recruitment to the infection site (JANEWAY et al., 2005).

Some researchers claim that TNF- $\alpha$ can cause clinical aggravation due to its pro-inflammatory activity (BEINEKE et al., 2008) whereas others believe that TNF- $\alpha$ would enhance the IFN- $\gamma$ protective effect against Anaplasma phagocytophilum (MARTIN; CASPERSEN; DUMLER, 2001). Martin, Carspersen and Dumler (2001) reported that IFN- $\gamma$ produced by macrophages activated during the inflammatory response would be inhibited by the IL-10 effect, which may also have happened in our study since we detected transitory high IL-10 levels and low INF- $\gamma$ levels. These findings have raised questions about cytokine role in animals and the immunopathological effects these cytokines expression would have in canine ehrlichiosis.

The findings of the present study suggest that E. canis Jaboticabal causes a dysfunction in the host's immune system with high TNF- $\alpha$ expression, indicating its importance in the disease pathogenesis. Besides, treatment with doxycycline hyclate can reduce parasitemia to undetectable levels and this cytokine's systemic effects.

\section{References}

BEINEKE, A. et al. Increase of pro-inflammatory cytokine expression in non-demyelinating early cerebral lesions in nervous canine distemper. Viral Immunology, v. 21, n. 4, p. 401-410, 2008.
CASTRO, M. B. et al. Experimental acute canine monocytic erhlichiosis: clinicopathological and immunopathological findings. Veterinary Parasitology, v. 119, n. 1, p. 73-86. 2004.

CHAMIZO, C. et al. Semi-quantitative analysis of multiple cytokines in canine peripheral blood mononuclear cells zby a single tube RT-PCR. Veterinary Immunology and Immunopathology, v. 83, n. 3-4, p. 191-202, 2001.

DUMLER, J. S. et al. Reorganization of genera in the families Rickettsiaceae and Anaplasmataceae in the order Rickettsiales: unification of some species of Ehrlichia with Anaplasma, Cowdria with Ehrlichia and Ehrlichia with Neorickettsia, descriptions of six new species combinations and designation of Ehrlichia equi and HGE agent as subjective synonyms of Ehrlichia phagocytophila. International Journal of Systematic and Evolutionary Microbiology, v. 51, n. 6, p. 2145-2165, 2001.

EDDLESTONE, S. M. et al. Doxycycline clearance of experimentally induced chronic Ehrlichia canis infection in dogs. Journal of Veterinary Internal Medicine, v. 21, n. 6, p. 1237-1242, 2007.

ELIAS, E. Diagnosis of ehrlichiosis from the presence of inclusion bodies or morulae of E. canis. Journal of Small Animal Practice, v. 33, n. 11, p. 540-543, 1991.

FARIA, J. L. M. et al. Erlichia canis morulae and DNA detection in whole blood and spleen aspiration samples. Revista Brasileira de Parasitologia Veterinária, v. 19, n. 2, p. 98-102, 2010.

FENG, H. M.; WALKER, D. H. Mechanisms of immunity to Ehrlichia muris: a model of monocytotropic ehrlichiosis. Infection and Immunity, v. 72, n. 2, p. 966-971, 2004.

HARRUS, S. et al. Amplification of ehrlichial DNA from dogs 34 months after infection with Ehrlichia canis. Journal of Clinical Microbiology, v. 36, n. 1, p. 73-76, 1998.

HARRUS, S. et al. Recent advances in determining the pathogenesis of canine monocytic ehrlichiosis. Journal of Clinical Microbiology, v. 37, n. 9, p. 2745-2749, 1999.

JANEWAY Jr., C. A. et al. Immunobiology: the immune system in health and disease. $6^{\text {th }}$ ed. London: Garland Science Publishing, 2005. 778 p.

MARTIN, M. E.; CARSPERSEN, K.; DUMLER, J. S. Immunopathology and ehrlichial propagation are regulated by interferon- $\gamma$ and interleukin- 10 in a murine model of human granulocytic ehrlichiosis. American Journal of Pathology, v. 158, n. 5, p. 1881-1888, 2001. 
MYLONAKIS, M. E. et al. Evaluation of cytology in the diagnosis of acute canine monocytic ehrlichiosis (Ehrlichia canis): a comparison between five methods. Veterinary Microbiology, v. 91, n. 2-3, p. 197-204, 2003.

NAKAGHI, A. C. H. et al. Canine ehrlichiosis: clinical, hematological, serological and molecular aspects. Ciência Rural, v. 38, n. 3, p. 766-770, 2008.

NEER, M. T.; HARRUS, S. Ehrlichiosis, Neorickettsiosis, Anaplasmosis and Wolbachia infection. In: GREENE, C. E. Infectious diseases of the dog and cat. $3^{\text {rd }}$ ed. Philadelphia: Elsevier, 2006. P. 203-216.

OLIVEIRA, D. et al. Anti-Ehrlichia canis antibodies detection by "DotELISA" in naturally infected dogs. Revista Brasileira de Parasitologia Veterinária, v. 9, n. 1, p. 1-5, 2000.
SCORPIO, D. G. et al. Innate immune response to Anaplasma phagocytophilum contributes to hepatic injury. Clinical and Vaccine Immunology, v. 13, n. 7, p. 806-809, 2006.

TAJIMA, T.; RIKIHISA,Y. Cytokine responses in dogs infected with Ehrlichia canis Oklahoma strain. Annals of the New York Academy of Science, n. 1063, p. 429-432, 2005.

UNVER, A.; HUANG, H.; RIKIHISA, Y. Cytokine gene expression by peripheral blood leukocytes in dogs experimentally infected with a new virulent strain of Ehrlichia canis. Annals of the New York Academy of Science, n. 1078, p. 482-486, 2006.

WANER, T. et al. Detection of platelet-bound antibodies in beagle dogs after artificial infection with Ehrlichia canis. Veterinary Immunology and Immunopatology, v. 77, n. 1-2, p. 145-150, 2000. 